\title{
The effectiveness and cost-effectiveness of screening for active tuberculosis among migrants in the EU/EEA: a systematic review
}

Christina Greenaway ${ }^{1,2}$, Manish Pareek ${ }^{3}$, Claire-Nour Abou Chakra4, Moneeza Walji2, Iuliia Makarenko², Balqis Alabdulkarim², Catherine Hogan ${ }^{1,2}$, Ted McConnell ${ }^{2}$, Brittany Scarfo ${ }^{2}$, Robin Christensen 5 , Anh Tran ${ }^{6}$, Nick Rowbotham ${ }^{6}$, Teymur Noori7, Marieke J van der Werf7, Kevin Pottie ${ }^{8}$, Alberto Matteelli9, Dominik Zenner ${ }^{10,11}$, Rachael L Morton ${ }^{6}$

1. Division of Infectious Diseases, Jewish General Hospital, McGill University, Montreal, Canada

2. Centre for Clinical Epidemiology of the Lady Davis Institute for Medical Research, Jewish General Hospital, Montreal, Canada

3. Department of Infection, Immunity and Inflammation, University of Leicester, Leicester, United Kingdom

4. Department of Microbiology and Infectious Diseases, Université de Sherbrooke, Québec, Canada

5. Musculoskeletal Statistics Unit, The Parker Institute, Bispebjerg and Frederiksberg Hospital, Copenhagen, Denmark

6. National Health and Medical Research Council (NHMRC) Clinical Trials Centre, University of Sydney, Sydney, Australia

7. European Centre for Disease Prevention and Control, Stockholm, Sweden

8. C.T. Lamont Primary Health Care Research Centre, Bruyère Research Institute, Ottawa, Ontario, Canada

9. Clinic of Infectious and Tropical Diseases, University of Brescia and Brescia Spedali Civili General Hospital, World Health Organization Collaborating Centre for TB/HIV and TB Elimination, Brescia, Italy

10. Respiratory Diseases Department, Centre for Infectious Disease Surveillance and Control (CIDSC), Public Health England, London, United Kingdom

11. Department of Infection and Population Health, University College London, London, United Kingdom

Correspondence: Christina Greenaway (ca.greenaway@mcgill.ca)

Greenaway Christina, Pareek Manish, Abou Chakra Claire-Nour, Walji Moneeza, Makarenko Iuliia, Alabdulkarim Balqis, Hogan Catherine, McConnell Ted, Scarfo Brittany, Christensen Robin, Tran Anh, Rowbotham Nick, Noori Teymur, van der Werf Marieke J, Pottie Kevin, Matteelli Alberto, Zenner Dominik, Morton Rachael L. The effectiveness and cost-effectiveness of screening for active tuberculosis among migrants in the EU/EEA: a systematic review. Euro Surveill. 2018;23(14):pii=1700542. https://doi.org/10.2807/1560-7917.ES.2018.23.14.17-00542

Background: The foreign-born population make up an increasing and large proportion of tuberculosis (TB) cases in European Union/European Economic Area (EU/ EEA) low-incidence countries and challenge TB elimination efforts. Methods: We conducted a systematic review to determine effectiveness (yield and performance of chest radiography (CXR) to detect active TB, treatment outcomes and acceptance of screening) and a second systematic review on cost-effectiveness of screening for active TB among migrants living in the EU/EEA. Results: We identified six systematic reviews, one report and three individual studies that addressed our aims. CXR was highly sensitive ( $98 \%$ ) but only moderately specific (75\%). The yield of detecting active TB with CXR screening among migrants was 350 per 100,000 population overall but ranged widely by host country (110-2,340), migrant type (170-1,192), TB incidence in source country (19-336) and screening setting $(220-1,720)$. The CXR yield was lower (19.6 vs $336 / 100,000)$ and the numbers needed to screen were higher (5,076 vs 298) among migrants from source countries with lower TB incidence $(\leq 50$ compared with $\geq 350 / 100,000$ ). Cost-effectiveness was highest among migrants originating from high $(>120 / 100,000)$ TB incidence countries. The foreign-born had similar or better TB treatment outcomes than those born in the EU/EEA. Acceptance of CXR screening was high (85\%) among migrants. Discussion: Screening programmes for active TB are most efficient when targeting migrants from higher TB incidence countries. The limited number of studies identified and the heterogeneous evidence highlight the need for further data to inform screening programmes for migrants in the EU/EEA.

\section{Introduction}

Tuberculosis (TB) is a public health priority in the European Union (EU) and European Economic Area (EEA), and countries have committed themselves to the World Health Organization (WHO) End TB Strategy with an ambitious goal to end TB [1-4]. The foreign-born population make up an increasing and considerable number and proportion of all TB cases in countries with low TB incidence ( 10 cases/100,000 population) and challenge TB elimination efforts in the EU/EEA [3,5]. More than one quarter of reported TB cases in 2015 in the EU/EEA occurred in the foreign-born population [5]. This proportion has been increasing steadily; in 2007 , $13.6 \%$ of TB cases occurred in migrant populations whereas in 2013 , they accounted for $21.8 \%$ [6]. In many low TB incidence countries in the EU/EEA, more than half of all TB cases occur among foreign-born individuals [5]. Between 2007 and 2012, the EU/EEA received on average 1.5 million migrants from outside of the EU/EEA, and larger numbers in 2015 and 2016 [7,8]. As a result, the foreign-born population now makes 


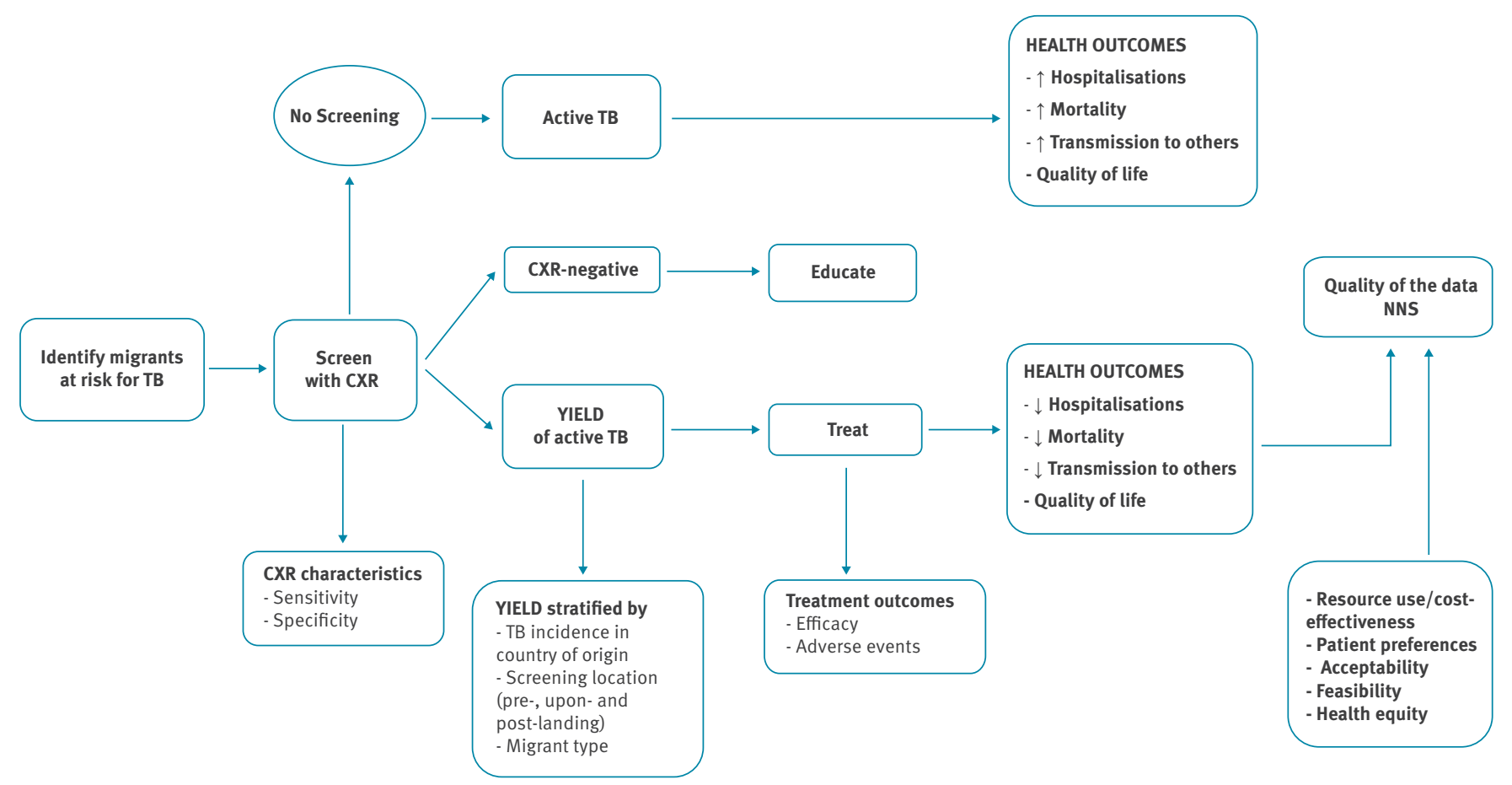

CXR: chest radiography; NNS: number needed to screen; TB: tuberculosis.

up $11.4 \%$ of the population in the EU/EEA and exceeds $15 \%$ in many low TB incidence countries $[7,8]$. A considerable proportion of these migrants were born in countries with a high TB burden $[9,10]$.

Given the disproportionate TB case notifications in migrant populations and the faster decline of $T B$ rates in host populations, enhanced TB control strategies among migrants will be necessary to achieve TB elimination in the EU/EEA (defined as achieving a rate of less than one case of TB per 1,000,000 population) $[1-4,11,12]$. Countries have generally focused on two targeted control strategies among migrants: (i) identification of active TB with chest radiography (CXR) before or soon after arrival in the host country to detect prevalent TB cases and limit onward transmission and (ii) more recently, identifying and treating latent $T B$ in migrants from high TB burden countries to prevent TB reactivation [13]. Many EU/EEA countries with low TB incidence screen migrants for active TB on or soon after arrival. The migrant groups targeted for screening and the location of screening are different for each country because screening guidelines for active TB in migrants are lacking at the EU/EEA level [13-15]. We conducted a systematic review on the effectiveness and a second systematic review on the cost-effectiveness of screening for active TB among migrants in the EU/EEA region with the aim of informing migrant screening guidelines.

\section{Methods}

Overall approach and key questions

This review supports a project of the European Centre for Disease Prevention and Control (ECDC) to develop guidance on screening for six infectious diseases (chronic hepatitis C, hepatitis B, HIV, TB (active and latent) and intestinal parasites) in newly arrived migrants to the EU/EEA. The project followed the new Grading of Recommendations Assessment, Development and Evaluation (GRADE)-ADOLOPMENT approach to conduct systematic reviews on screening migrant populations for these six infectious diseases [16]. The review protocol and the methods of GRADE-ADOLOPMENT guideline development have been published $[16,17]$. All reviews followed a Cochrane methodological approach and the Preferred Reporting Items for Systematic Reviews and Meta-Analyses (PRISMA) methods for reporting systematic reviews [18]. For each review, we developed two research questions (using a population, intervention, comparison and outcome (PICO) framework), an analytic framework to illustrate the screening evidence pathway, and identified and prioritised clinically important outcomes, following the evidence-based review methods described by the United States (US) Preventative Task Force $[19,20]$. We sought to answer two research questions: (i) what is the effectiveness of screening migrants arriving and living in the EU/EEA for active TB and (ii) what is the resource use, cost and cost-effectiveness of screening migrants for active TB? 
PRISMA flow diagram, literature search for the effectiveness and cost-effectiveness of active tuberculosis screening, 1 January 2005-12 May 2016

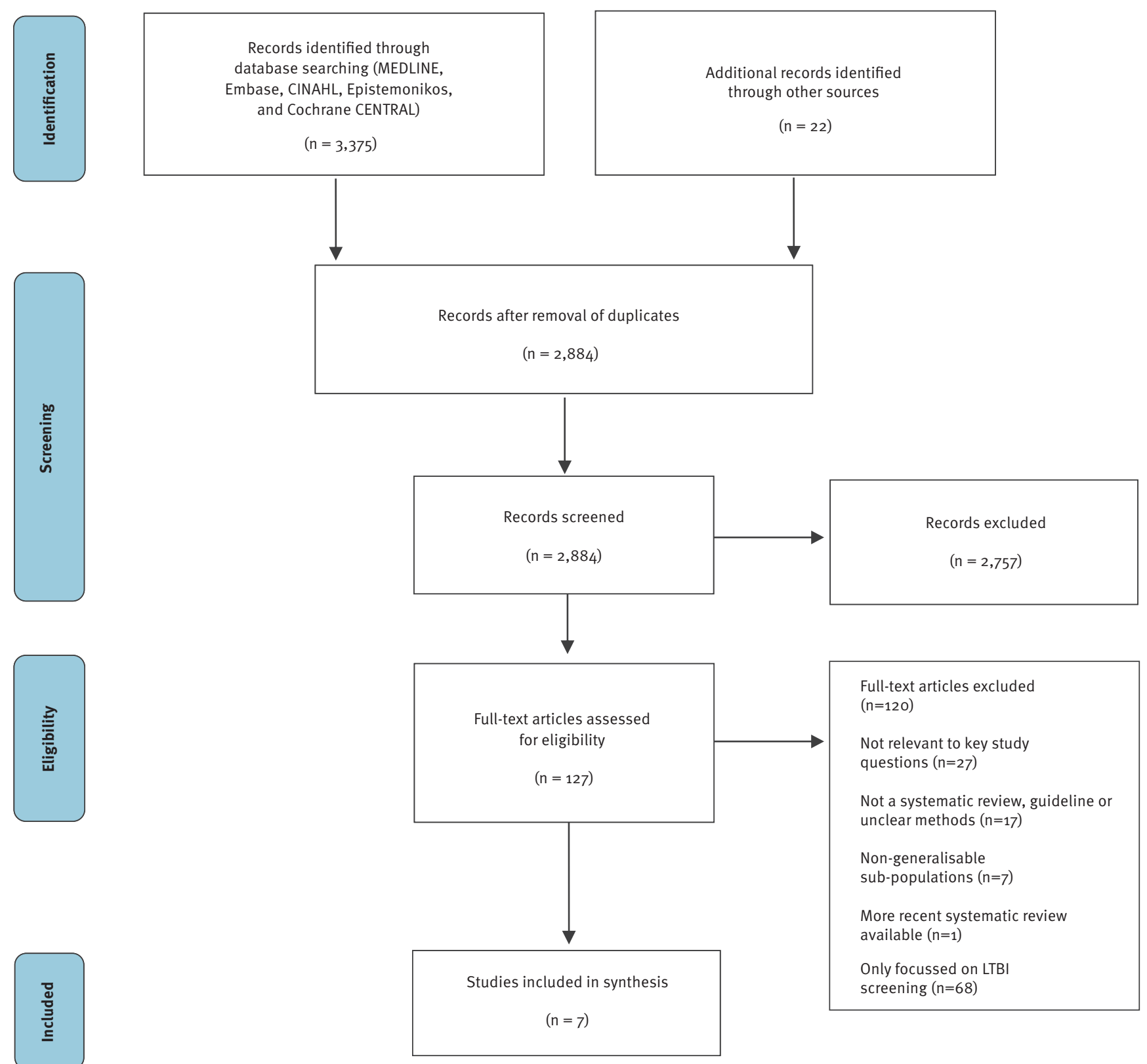

CINAHL: Cumulative Index to Nursing and Allied Health Literature; LTBI: latent tuberculosis infection.

We developed an analytic framework that identified the evidence chain to address the effectiveness and costeffectiveness of active TB screening among migrants (Figure 1) [17]. We developed the following key questions along this evidence chain: (i) what is the yield of active TB screening with CXR in migrants, (ii) what are the test performance characteristics of CXR to detect active TB, (iii) how effective is active TB therapy and what are the associated harms, (iv) what is the uptake of active TB screening by migrants, and (v) how costeffective is screening for active TB in migrants [17]?

\section{Search strategy and selection criteria}

Following the GRADE-ADOLOPMENT process, we identified an evidence review that assessed the effectiveness of latent TB infection (LTBI) screening among migrants, published in 2011 by the Canadian Collaboration on Immigrant and Refugee Health (CCIRH), and used this as a starting point for our literature search (anchoring review) $[16,21]$. The CCIRH review included systematic reviews on the effectiveness of LTBI screening in migrants up to 2008 but did not review cost-effectiveness. We therefore conducted two separate searches to address our research questions. The first search 


\section{FIGURE 3}

PRISMA flow diagram, literature search for the resource use, costs and cost-effectiveness of active tuberculosis screening, 1 January 2000-31 May 2016

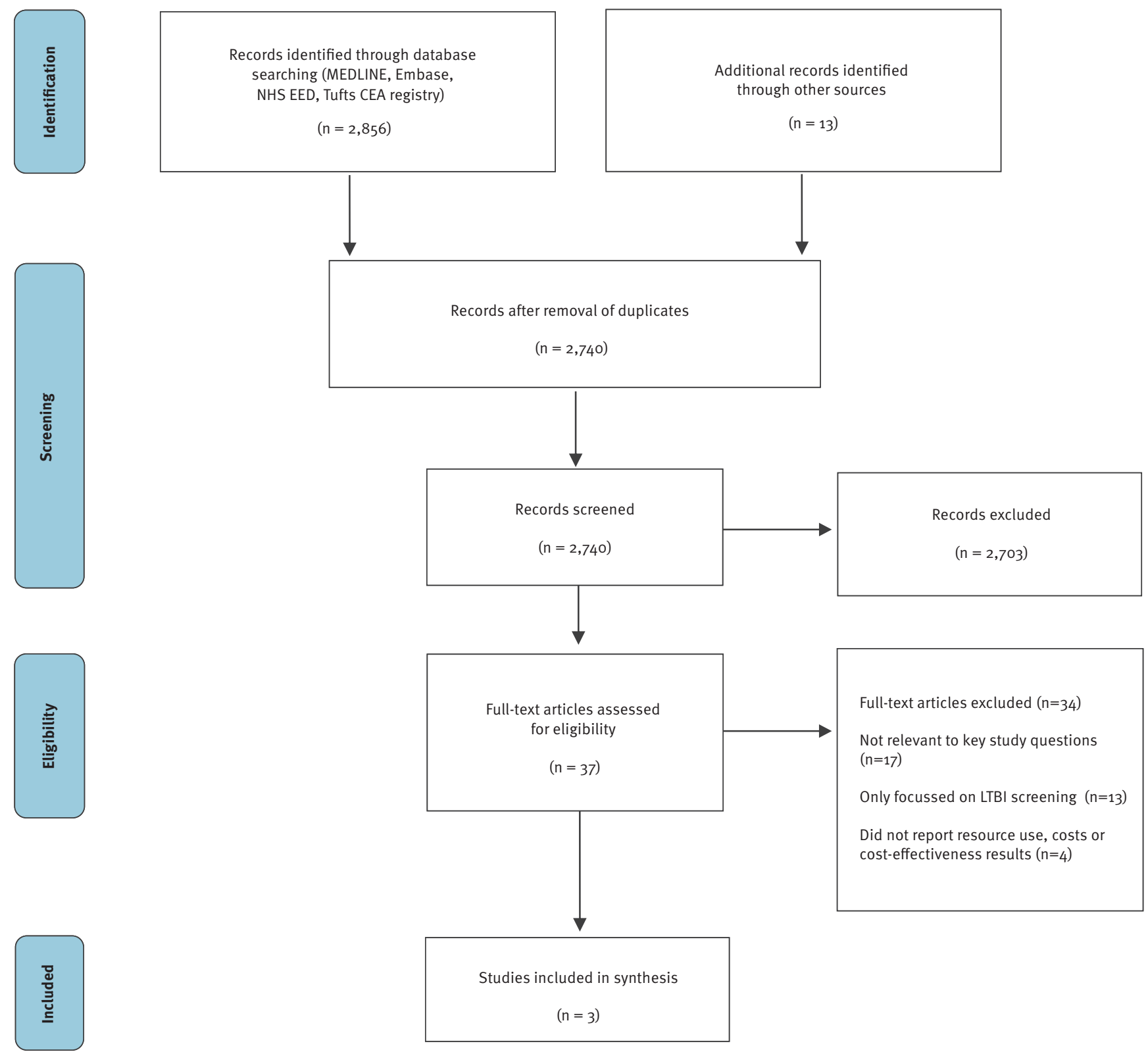

LTBI: latent tuberculosis infection; NHS EED: National Health Service Economic Evaluation Database; Tufts CEA: Tufts Medical Center CostEffectiveness Analysis Registry.

updated the CCIRH evidence review and identified systematic reviews and guidelines on the effectiveness and cost-effectiveness of TB screening programmes in migrant populations from 2005 to 2016 . The second search identified individual studies on the resource use, costs and cost-effectiveness of TB screening programmes for migrants over a longer period, 2000 to 2016, given these topics were not covered in the CCIRH evidence review. For the first search, MEDLINE via Ovid, Embase, the Cumulative Index to Nursing and Allied Health Literature (CINAHL), Epistemonikos and Cochrane CENTRAL between 1 January 2005 and
12 May 2016 were searched. We used a combination of key terms including: 'tuberculosis', 'screening', 'chest-radiograph', 'tuberculin skin test', 'interferongamma release assays', 'costs', 'cost-effectiveness' AND 'guidelines' and 'reviews'. The search terms and strategy in Ovid MEDLINE are included in Supplement 1. We also searched grey literature websites for published guidelines and reports from the US Centres for Disease Control and Prevention (CDC), ECDC, WHO and the International Union Against Tuberculosis and Lung Disease (IUATLD). We did not apply language restrictions to the search. Additional guidelines and 
TABLE 1A

Characteristics of included studies for effectiveness of active tuberculosis screening

\begin{tabular}{|c|c|c|c|c|c|}
\hline Study & $\begin{array}{l}\text { Certainty of } \\
\text { evidence }\end{array}$ & Design & Population & $\begin{array}{l}\text { Intervention/ } \\
\text { outcomes }\end{array}$ & Results \\
\hline $\begin{array}{l}\text { Klinkenberg et } \\
\text { al. 2009 [29] }\end{array}$ & $\begin{array}{c}\text { Quality of } \\
\text { systematic } \\
\text { review } \\
\text { (AMSTAR): } \\
3 / 11 . \\
\\
\text { Quality of data } \\
\text { of included } \\
\text { individual } \\
\text { studies } \\
\text { (GRADE): low. }\end{array}$ & $\begin{array}{l}\text { Systematic } \\
\text { review } \\
\text { 1998-2008. } \\
\\
\text { Observational } \\
\text { studies: EU/ } \\
\text { EEA (n=36), } \\
\text { non-EU } \\
\text { (n=14). } \\
\\
\\
\text { EU countries } \\
\text { included: } \\
\text { Belgium, } \\
\text { Denmark, } \\
\text { France, } \\
\text { Germany, } \\
\text { Greece, } \\
\text { Ireland, } \\
\text { Italy, the } \\
\text { Netherlands, } \\
\text { Norway, } \\
\text { Spain, } \\
\text { Switzerland, } \\
\text { UK. }\end{array}$ & $\begin{array}{l}\text { New entrants to the EU/EEA: } \\
\text { migrant, asylum seeker, foreign- } \\
\text { born citizen, illegal foreigner/ } \\
\text { migrant. } \\
\text { Non-EU were performed in the US, } \\
\text { Canada, Australia and Japan. } \\
\\
\text { Type of screening: mandatory } \\
\text { (n=24,156), voluntary: ( } n=2,855) \text {. } \\
\\
\text { Type of migrant: asylum seekers: } \\
\text { ( } n=17,824) \text {, other migrants: } \\
(n=5,925), \text { migrants/asylum } \\
\text { seekers ( } n=218,565) \text {. }\end{array}$ & $\begin{array}{l}\text { Intervention: } \\
\text { screening by CXR } \\
\text { (at port of arrival, } \\
\text { reception/holding/ } \\
\text { transit centre, } \\
\text { community post- } \\
\text { arrival, occasional } \\
\text { screening, } \\
\text { follow-up } \\
\text { screening). } \\
\\
\text { Outcomes: yield of } \\
\text { active TB/100,000, } \\
95 \% \mathrm{CI}, \text { median and } \\
\text { IQR. }\end{array}$ & $\begin{array}{l}\text { Median active TB yield/100,000, } \\
\text { (IQR): EU countries: } 350 \\
(110-710), \text { non-EU countries: } 510 \\
(170-1,230) . \\
\text { Screening type: mandatory (EU): } \\
280 \text { (100-420); voluntary (EU): } \\
400 \text { (160-980). } \\
\text { Migrant type (EU): asylum } \\
\text { seeker: } 350(250-410), \text { other } \\
\text { migrant: } 170(100-630), \\
\text { migrant/asylum seeker: } 300 \\
\text { (9-500). } \\
\text { Screening setting (EU): port } \\
\text { of arrival: } 360 \text { (100-520), port } \\
\text { of arrival and community post } \\
\text { arrival: } 650 \text { (0-0), reception/ } \\
\text { holding centre: } 290(100-380), \\
\text { community post arrival: } 220 \\
\text { (100-380), follow-up: } 120 \\
\text { (90-170), occasional: } 1,720 \\
\text { (730-2,740), port of arrival and } \\
\text { occasional: } 720(710-1,000) \text {. }\end{array}$ \\
\hline $\begin{array}{l}\text { Arshad et al. } \\
2010 \text { [28] }\end{array}$ & $\begin{array}{l}\text { Quality of data } \\
\text { of included } \\
\text { individual } \\
\text { studies } \\
\text { (GRADE): low- } \\
\text { very low. }\end{array}$ & $\begin{array}{l}\text { EU countries } \\
\text { included: } \\
\text { Belgium } \\
\text { Denmark, } \\
\text { Ireland, the } \\
\text { Netherlands, } \\
\text { Norway, } \\
\text { Spain, } \\
\text { Switzerland, } \\
\text { UK. }\end{array}$ & $\begin{array}{c}\text { Migrants assessed through active } \\
\text { case finding or active screening } \\
\text { programme irrespective of } \\
\text { symptoms. } \\
n=5,446 \text { pulmonary TB, } \\
n=2,620,739 \text { screened migrants. } \\
\text { Total types of migrants } \\
\text { screened: asylum seekers } \\
(n=135,265), \text { regular immigrants } \\
(n=2,466,492), \text { refugees } \\
(n=18,982) .\end{array}$ & $\begin{array}{l}\text { Intervention: CXR } \\
\text { and/or sputum } \\
\text { smear and/or } \\
\text { microbiological } \\
\text { culture; routine } \\
\text { screening } \\
\text { programmes/on } \\
\text { purpose screening. } \\
\\
\text { Outcome: number } \\
\text { of cases detected } \\
\text { per 10o,0oo } \\
\text { individuals } \\
\text { screened (95\% CI). } \\
\\
\text { RR: pooled } \\
\text { prevalence } \\
\text { for pulmonary } \\
\text { tuberculosis among } \\
\text { screened migrants } \\
\text { compared with } \\
\text { general population } \\
\text { in host country } \\
\text { (95\% Cl). }\end{array}$ & $\begin{array}{l}\text { Active TB yield/100,000 ( } 95 \% \\
\text { CI): } 349(290-408) ; \text { RR }(95 \% \\
\text { CI): } 48.2(23.3-99.6) . \\
\\
\text { Immigrant class: refugees: } \\
\text { 1,192 (668-1,717); RR 130.6 } \\
\text { (58.8-290.2), migrants: } 284 \\
\text { (204-364); RR 29.4 (9.7- 88.9), } \\
\text { asylum seekers: } 270(198-342) ; \\
\text { RR 30.1 (19.3-47.1). }\end{array}$ \\
\hline
\end{tabular}

AMSTAR: A MeaSurement Tool to Assess systematic Reviews [22]; Cl: confidence interval; CXR: chest radiography; EEA: European Economic Area; EU: European Union; GRADE: The Grading of Recommendations Assessment, Development and Evaluation; HCW: healthcare workers; HIV: human immunodeficiency virus; IQR: interquartile range; LTBI: latent tuberculosis infection; N/A: not applicable; OR: odds ratio; PTB: pulmonary TB; QUADAS: Quality Assessment of Diagnostic Accuracy Studies; RR: risk ratio; SSA: sub-Saharan Africa; TB: tuberculosis; UK: United Kingdom; US: United States. 
Characteristics of included studies for effectiveness of active tuberculosis screening

\begin{tabular}{|c|c|c|c|c|c|}
\hline Study & $\begin{array}{l}\text { Certainty of } \\
\text { evidence }\end{array}$ & Design & Population & $\begin{array}{l}\text { Intervention/ } \\
\text { outcomes }\end{array}$ & Results \\
\hline $\begin{array}{l}\text { Aldridge et al. } \\
2014 \text { [25] }\end{array}$ & $\begin{array}{c}\text { Quality of } \\
\text { systematic } \\
\text { review } \\
\text { (AMSTAR): } \\
8 / 11 . \\
\\
\text { Quality of data } \\
\text { of included } \\
\text { individual } \\
\text { studies } \\
\text { (GRADE): very } \\
\text { low. }\end{array}$ & $\begin{array}{l}\begin{array}{c}\text { Systematic } \\
\text { review }\end{array} \\
1980-2014 . \\
n=15 \text { studies. }\end{array}$ & 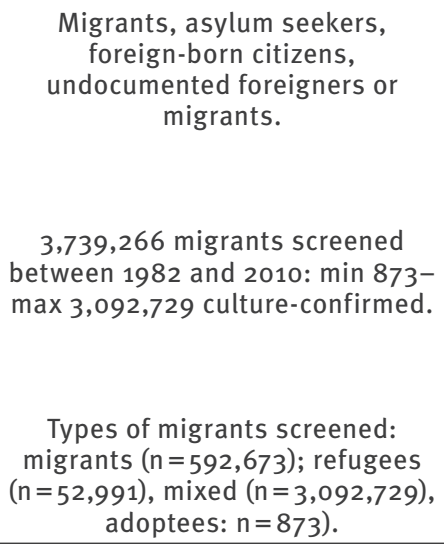 & $\begin{array}{l}\text { Interventions: CXR, } \\
\text { culture, smear for } \\
\text { acid-fact bacilli, } \\
\text { drug-resistant } \\
\text { disease, LTBI (any } \\
\text { method). } \\
\\
\text { Outcome: yield of } \\
\text { culture-confirmed } \\
\text { active TB per } \\
\text { 10o,ooo by TB } \\
\text { prevalence in } \\
\text { country of origin. }\end{array}$ & $\begin{array}{l}\text { TB incidence/100,000 person- } \\
\text { years at } 7 \text { years post migration: } \\
\text { Africa: } 190, \text { Asia: } 80, \\
\text { Somalia: } 520 \text {, Pakistan: } \\
\text { 160, Vietnam: } 210 \text {, Former } \\
\text { Yugoslavia: } 40 / 100,000 .\end{array}$ \\
\hline $\begin{array}{l}\text { Van't Hoog et } \\
\text { al. } 2013 \text { [30] }\end{array}$ & $\begin{array}{c}\text { Quality of } \\
\text { systematic } \\
\text { review } \\
\text { (AMSTAR): } \\
6 / 11 . \\
\\
\text { Quality of data } \\
\text { of included } \\
\text { individual } \\
\text { studies } \\
\text { (GRADE): very } \\
\text { low. }\end{array}$ & $\begin{array}{c}\begin{array}{c}\text { Systematic } \\
\text { review }\end{array} \\
1992-2012 \text {. } \\
\\
n=17 \\
\text { studies (24 } \\
\text { publications), } \\
11 \text { community } \\
\text { prevalence } \\
\text { surveys. }\end{array}$ & $\begin{array}{l}\text { Adults ( }>15 \text { years) or general } \\
\text { population undergoing first } \\
\text { screening (HIV-negative and } \\
\text { unknown HIV status). }\end{array}$ & $\begin{array}{c}\text { Intervention: } \\
\text { symptoms, CXR, } \\
\text { combinations. } \\
\\
\text { Outcomes: } \\
\text { sensitivity and } \\
\text { specificity }(95 \% \mathrm{Cl}) \\
\text { to detect active TB. }\end{array}$ & $\begin{array}{l}\text { CXR screening had greater } \\
\text { accuracy compared with } \\
\text { symptoms screening. } \\
\text { CXR with any abnormality: } \\
\text { sensitivity (95\% CI): } 97.8 \% \\
\text { (95.1-100.0), specificity (95\% } \\
\text { CI): } 75.4 \% \text { (72.0-78.8). } \\
\text { CXR with abnormality } \\
\text { suggestive of TB: sensitivity: } \\
\text { 86.8\% (79.2-94.5), specificity: } \\
\text { 89.4\% (86.7-92.0). } \\
\text { Any symptom screening: } \\
\text { High HIV/SSA: sensitivity: } \\
\text { 84.2\% (75.6-92.7), specificity: } \\
\text { 74.0\% (53.1-94.9). } \\
\text { Low HIV/Asia: sensitivity: } 69.8 \% \\
\text { (57.9-81.8), specificity: } 60.6 \% \\
\text { (34.7-86.0). } \\
\text { Low and high HIV combined: } \\
\text { sensitivity: } 77.0 \%(68.0-86.0), \\
\text { sensitivity: } 67.7 \%(50.2-85.1) .\end{array}$ \\
\hline
\end{tabular}

AMSTAR: A MeaSurement Tool to Assess systematic Reviews [22]; Cl: confidence interval; CXR: chest radiography; EEA: European Economic Area; EU: European Union; GRADE: The Grading of Recommendations Assessment, Development and Evaluation; HCW: healthcare workers; HIV: human immunodeficiency virus; IQR: interquartile range; LTBI: latent tuberculosis infection; N/A: not applicable; OR: odds ratio; PTB: pulmonary TB; QUADAS: Quality Assessment of Diagnostic Accuracy Studies; RR: risk ratio; SSA: sub-Saharan Africa; TB: tuberculosis; UK: United Kingdom; US: United States.

studies were identified by our co-authors and through searching bibliographies of included studies. In the second search, using the search terms 'tuberculosis', 'screening', 'costs' and 'cost-effectiveness', we searched MEDLINE, Embase, the National Health Service Economic Evaluation Database (NHS EED), the Database of Abstracts of Reviews of Effects (DARE), the Tufts Medical Center Cost-Effectiveness Analysis Registry and Google Scholar for entries between 1 January 2000 and 31 May 2016.

\section{Study selection and quality assessment}

We identified and included systematic reviews and evidence-based guidelines that directly addressed each key question along the active TB screening evidence chain and prioritised documents focusing on newly arrived ( $<5$ years in the host country) migrants. Migrant populations included were non-forced economic migrants, and refugees, asylum seekers and illegal migrants who may have been forced to flee conflict, natural disaster, or economic peril [17]. We only included studies published in full and in English 
Characteristics of included studies for effectiveness of active tuberculosis screening

\begin{tabular}{|c|c|c|c|c|c|}
\hline Study & $\begin{array}{l}\text { Certainty of } \\
\text { evidence }\end{array}$ & Design & Population & $\begin{array}{l}\text { Intervention/ } \\
\text { outcomes }\end{array}$ & Results \\
\hline $\begin{array}{l}\text { Pinto et al. } \\
2013 \text { [31] }\end{array}$ & $\begin{array}{c}\text { Quality of } \\
\text { systematic } \\
\text { review } \\
\text { (AMSTAR): } \\
8 / 11 . \\
\\
\text { Quality of data } \\
\text { of included } \\
\text { individual } \\
\text { studies not } \\
\text { mentioned but } \\
\text { all studies had } \\
\text { verification } \\
\text { bias (assessed } \\
\text { by QUADAS): } \\
54 \% \text { not } \\
\text { representative, } \\
46 \% \text { did } \\
\text { not mention } \\
\text { blinding. }\end{array}$ & $\begin{array}{l}\begin{array}{c}\text { Systematic } \\
\text { review }\end{array} \\
\text { up to } 2012 \text {. } \\
\\
\mathrm{n}=12 \text { studies } \\
\text { with combined } \\
\text { clinical and } \\
\text { radiographic } \\
\text { features, } 1 \\
\text { with clinical } \\
\text { prediction } \\
\text { rules. }\end{array}$ & $\begin{array}{l}\text { Adult patients ( } \geq 15 \text { years) } \\
\text { with possible PTB (excluding } \\
\text { pneumoconiosis, malignancies, } \\
\text { immune-mediated inflammatory } \\
\text { disease or haemodialysis). }\end{array}$ & $\begin{array}{l}\text { Intervention: CXR } \\
\text { scoring system. } \\
\\
\text { Outcomes: } \\
\text { sensitivity and } \\
\text { specificity (95\% } \\
\text { CI) with no pooling } \\
\text { (median, range } \\
\text { presented), } \\
\text { diagnostic OR: odds } \\
\text { of patient with PTB } \\
\text { and specific clinical } \\
\text { or radiographic } \\
\text { feature(s)/odds } \\
\text { without PTB and } \\
\text { having the same } \\
\text { feature(s). }\end{array}$ & $\begin{array}{c}\text { Significantly associated with } \\
\text { pulmonary TB: upper lobe } \\
\text { infiltrates: OR }(95 \% \text { CI):3.57 } \\
(2.38-5.37) \text {, cavities diagnostic: } \\
\text { OR range: } 1.97-25.66 . \\
\text { Scoring systems characteristics: } \\
\text { sensitivity: median 96\%, IQR: } \\
\text { 93-98\%, sensitivity: median } \\
\text { 46\%, IQR: } 35-50 \% \text {. }\end{array}$ \\
\hline $\begin{array}{l}\text { Ködmön et al. } \\
2016 \text { [6] }\end{array}$ & $\begin{array}{c}\text { High quality } \\
\text { individual } \\
\text { study } \\
\text { (assessed by } \\
\text { New Castle- } \\
\text { Ottawa): } 8 / 8 \text {. }\end{array}$ & $\begin{array}{l}\text { Public health } \\
\text { surveillance } \\
\text { of reported } \\
\text { active TB } \\
\text { cases from } \\
\text { EU and EEA } \\
\text { countries } \\
2007-2013 . \\
\\
29 \text { countries. }\end{array}$ & $\begin{array}{c}527,467 \text { TB cases reported, } \\
491,652 \text { with reported country of } \\
\text { origin, } 91,925 \text { cases from outside } \\
\text { EU/EEA. }\end{array}$ & $\begin{array}{l}\text { Intervention: N/A. } \\
\\
\text { Outcomes: } \\
\text { successful } \\
\text { treatment: cured } \\
\text { case or treatment } \\
\text { completed after } \\
12 \text { months, death } \\
\text { during treatment. }\end{array}$ & $\begin{array}{c}\text { Number of reported TB } \\
\text { treatment outcome: EU/EEA: } \\
\text { 86\%, non-EU/EEA: } 82 \% . \\
\text { Treatment success (24 } \\
\text { countries): EU/EEA: } 74.6 \%, \\
\text { non-EU/EEA: } 77.4 \% . \\
\text { Treatment failure: EU/EEA: } 2.3 \% \text {, } \\
\text { non-EU/EEA: } 0.2 \% . \\
\text { Lost to follow-up: EU/EEA: } 6.6 \% \text {, } \\
\text { non-EU/EEA: } 5.4 \% . \\
\text { Death during treatment: EU/EEA: } \\
8.2 \%, \text { non-EU/EEA: } 3.2 \% .\end{array}$ \\
\hline $\begin{array}{l}\text { Mitchell et al. } \\
2013 \text { [32] }\end{array}$ & $\begin{array}{c}\text { Quality of } \\
\text { studies } \\
\text { judged to have } \\
\text { significant } \\
\text { degree of } \\
\text { heterogeneity } \\
\text { and reporting } \\
\text { and publication } \\
\text { bias. The } \\
\text { tool used } \\
\text { to measure } \\
\text { bias was not } \\
\text { mentioned. }\end{array}$ & $\begin{array}{l}\text { Qualitative } \\
\text { and } \\
\text { quantitative } \\
\text { systematic } \\
\text { review } \\
\text { and meta- } \\
\text { synthesis. }\end{array}$ & $\begin{array}{l}\text { (ii) Congregate/occupational/ } \\
\text { environmental (elderly, HCWs, } \\
\text { prisoners etc.). } \\
\text { (iii) Behavioural/marginalised risk } \\
\text { groups (homeless, migrants, sex } \\
\text { workers etc). }\end{array}$ & $\begin{array}{l}\text { Outcome: } \\
\text { proportion of } \\
\text { eligible persons } \\
\text { who consented } \\
\text { to undergo TB } \\
\text { screening, per risk- } \\
\text { group (equivalent of } \\
\text { recruitment rate). }\end{array}$ & $\begin{array}{l}\text { Simple TB screening (at point- } \\
\text { of-care) more acceptable than } \\
\text { referral on multiple visits. } \\
\text { Inclusion of HIV testing may be } \\
\text { a deterrent in some risk groups. } \\
\text { TB screening and treatment are } \\
\text { low priority for groups facing } \\
\text { housing insecurity, addiction, } \\
\text { threat of violence, deportation. } \\
\text { Screening in hard-to-reach } \\
\text { populations is more acceptable } \\
\text { if benefits are immediate and } \\
\text { tangible. Acceptability of TB } \\
\text { screening is dependent on } \\
\text { quality of human interaction } \\
\text { as well as perceived negative } \\
\text { consequences. }\end{array}$ \\
\hline
\end{tabular}

AMSTAR: A MeaSurement Tool to Assess systematic Reviews [22]; CI: confidence interval; CXR: chest radiography; EEA: European Economic Area; EU: European Union; GRADE: The Grading of Recommendations Assessment, Development and Evaluation; HCW: healthcare workers; HIV: human immunodeficiency virus; IQR: interquartile range; LTBI: latent tuberculosis infection; N/A: not applicable; OR: odds ratio; PTB: pulmonary TB; QUADAS: Quality Assessment of Diagnostic Accuracy Studies; RR: risk ratio; SSA: sub-Saharan Africa; TB: tuberculosis; UK: United Kingdom; US: United States. 
TABLE 2

Numbers needed to screen to detect one case of active tuberculosis

\begin{tabular}{|c|c|c|c|c|}
\hline TB prevalence in country of origin $/ 100,000$ & $\begin{array}{l}\text { Yield of culture-confirmed active } \\
\text { TB } / 100,000^{\mathrm{a}}\end{array}$ & $95 \% \mathrm{Cl}$ & NNS $^{b}$ & $95 \% \mathrm{Cl}$ \\
\hline $50-149$ & 19.7 & $10.3-31.6$ & 5,076 & $3,175-9,709$ \\
\hline $150-249$ & 166.2 & $140-194$ & 602 & $514-714$ \\
\hline $250-349$ & 133.5 & $111-158$ & 749 & $631-903$ \\
\hline$>350$ & 335.9 & $283-393$ & 298 & $254-353$ \\
\hline
\end{tabular}

$\mathrm{Cl}$ : confidence interval; CXR: chest radiography; NNS: numbers needed to screen; TB: tuberculosis.

a The yield of active TB detection in pre-arrival CXR screening programmes for migrants by TB incidence in country of origin from Aldrige et al. [25].

${ }^{b}$ NNS $=1 /$ mean prevalence of active TB found through CXR screening stratified by TB incidence in the country of origin.

or French. If more than one version of a systematic review was identified, the most recent was considered. Studies were excluded if they were not relevant to the key questions, if they were not a systematic review or guideline, if the study methodology was unclear, and if they focussed only on non-generalisable subgroups (such as healthcare workers or HIV-positive people) or addressed only latent TB screening. Two authors screened the titles and abstracts, assessed selected full-text articles for eligibility and extracted data from included articles. Disagreements were resolved by consensus or by a third author. The methodological quality of systematic reviews was assessed using the AMSTAR tool (A Measurement Tool to Assess Systematic Reviews) and the quality of individual studies was assessed with the Newcastle-Ottawa scale [22,23]. The GRADE criteria were applied to assess the quality and certainty of the evidence for the individual studies included in the systematic reviews [24].

\section{Data extraction and synthesis}

The following information was extracted from each study: study design, objectives, analyses, quality assessment of the individual studies included in the systematic review, population examined, number of included studies, total number of participants included, intervention, outcome and results. We created GRADE evidence profiles and summary of findings tables for each outcome where appropriate. Numbers needed to screen (NNS) were estimated by calculating $1 /$ mean prevalence of active TB found through CXR screening stratified by TB incidence in the country of origin as reported in the study by Aldridge et al. [25].

For each of the cost-effectiveness studies, we extracted the following data: economic methods used (e.g. microcosting study, within-trial cost-utility analysis, Markov model), description of the case base population, the intervention and comparator, the absolute size and relative difference in resource use and cost-effectiveness (e.g. incremental net benefit (INB) or incremental costeffectiveness ratio (ICER)) [26]. The certainty of economic evidence in each study was assessed using the relevant items from the 1997 Drummond checklist [27]. All currencies were converted to 2015 Euros using the
Cochrane web-based currency conversion tool: https:// eppi.ioe.ac.uk/costconversion/default.aspx.

\section{Results}

In the first search, we retrieved 3,375 studies through database searching and 22 additional studies identified through other sources on the effectiveness of TB screening in migrant populations (Figure 2). After removal of duplicates, 2,884 studies were screened by title and abstract. A total of 127 studies underwent full text assessment. We did not identify any single study on the effectiveness of active TB screening in migrants. We therefore included seven studies that addressed the active TB screening evidence chain: the yield of detecting active TB among migrants in CXR screening programmes $(n=3)[25,28,29]$, the performance characteristics of CXR to detect active TB $(n=2)[30,31]$, the effectiveness of TB therapy in those born in the EU/ EEA and the foreign-born population $(n=1)[6]$, and the uptake of active TB screening by migrants $(n=1)$ [32]. In the second search, 2,856 articles were retrieved through database searching and an additional 13 articles identified through other resources (Figure 3). After removal of duplicates, 2,740 studies were screened by title and abstract. A total of 37 studies underwent full text assessment and three individual studies were included for analysis [33-35].

\section{Effectiveness of active tuberculosis screening}

Yield of chest radiography to detect active tuberculosis Three systematic reviews assessed the yield of detecting active TB among migrant populations in CXR screening programmes performed before and after arrival in the EU/EEA and low TB incidence countries outside the EU/EEA $[25,28,29]$. The yield of active TB was heterogeneous across studies, varied by migrant type and the setting in which the screening was done and was consistently higher with higher TB incidence in the country of origin (Table 1 ).

Klinkenberg et al. found that the overall yield of active TB screening programmes in migrants upon and after arrival in 26 studies done in EU/EEA countries was 350 per 100,000 population [29]. The yield differed by 
TABLE 3A

Characteristics of included studies for resource use, costs, and cost-effectiveness of active tuberculosis screening

\begin{tabular}{|c|c|c|c|c|c|}
\hline Study & $\begin{array}{c}\text { Certainty of economic evidence } \\
\text { based on the Drummond } \\
\text { criteria }^{\text {a }} \text { [27] }\end{array}$ & Methodological approach/population & Intervention(s) & $\begin{array}{l}\text { Cost-effectiveness } \\
\text { (ICER or INB) per } \\
\text { case prevented }\end{array}$ & $\begin{array}{c}\text { Resource } \\
\text { Requirements }\end{array}$ \\
\hline $\begin{array}{l}\text { Schwartzman et } \\
\text { al. } 2000 \text { [33] }\end{array}$ & $\begin{array}{l}\text { Certainty of evidence: } \\
\text { moderate. } \\
\text { Allowance was made for } \\
\text { uncertainty in the estimates of } \\
\text { costs and consequences, and } \\
\text { ranges were provided. } \\
\text { No PSA were performed. } \\
\text { Justification was provided for } \\
\text { a range of values estimated in } \\
\text { one-way sensitivity analyses. } \\
\text { The cost-effectiveness results } \\
\text { were sensitive to model inputs } \\
\text { including the probability of } \\
\text { INH prescribed; probability } \\
\text { of INH treatment completed; } \\
\text { cost of inpatient treatment; } \\
\text { TB infection rate and HIV } \\
\text { seropositivity. }\end{array}$ & $\begin{array}{l}\text { Methods: decision-analytic Markov } \\
\text { model; } 20 \text { year time horizon; } 3 \% \\
\text { discount rate, perspective of the } \\
\text { third-party payer (central and } \\
\text { provincial governments); scenario } \\
\text { analysis based on INH completion } \\
\text { conducted. } \\
\text { Population: } 20 \text {-year-old immigrants to } \\
\text { Canada originating from Sub-Saharan } \\
\text { Africa, South-east Asia, Western } \\
\text { Europe. } \\
\text { Cohort 1: } 50 \% \text { TB-positive, } 10 \% \text { HIV- } \\
\text { positive. } \\
\text { Cohort 2: } 50 \% \text { TB-positive, } 1 \% \text { HIV- } \\
\text { positive. } \\
\text { Cohort 3: } 5 \% \text { TB-positive, } 1 \% \\
\text { HIV-positive. }\end{array}$ & $\begin{array}{l}\text { Three strategies: } \\
\text { (i) No screening } \\
\text { (ii) CXR } \\
\text { (iii) TST }\end{array}$ & 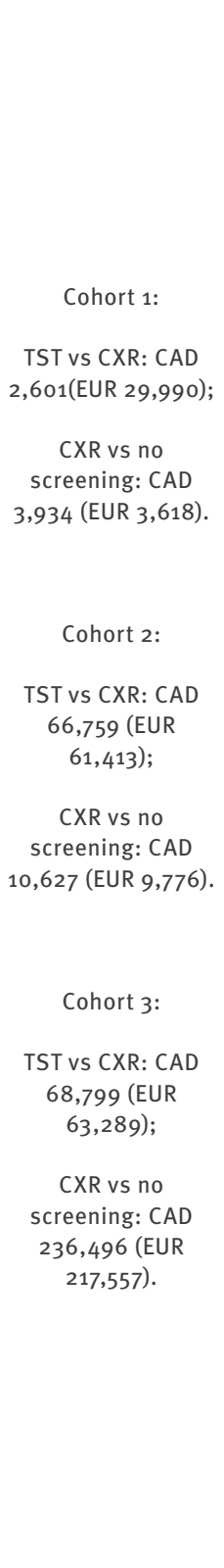 & 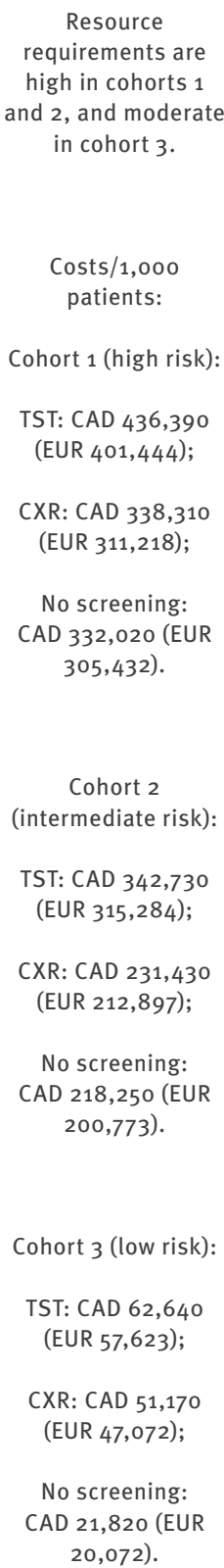 \\
\hline
\end{tabular}

CAD : Canadian dollar; CXR: chest radiography; EUR: Euro; HIV: human immunodeficiency virus; ICER: incremental cost-effectiveness ratio; INB: incremental net benefit; INH: isoniazid; PSA: probabilistic sensitivity analysis; QFT: quantiferon; TB: tuberculosis; TST: tuberculin skin test; USD: United States dollar.

a The Drummond Criteria [27]: (i) Was a well-defined question posed in answerable form? (ii) Was a comprehensive description of the competing alternatives given (i.e. can you tell who did what to whom, where and how often)? (iii) Was the effectiveness of the programme or services established? (iv) Were all the important and relevant costs and consequences for each alternative identified? (v) Were costs and consequences measured accurately in appropriate physical units (e.g. hours of nursing time, number of physician visits, lost working days, gained life years)? (vi) Were the cost and consequences valued credibly? (vii) Were costs and consequences adjusted for differential timing? (viii) Was an incremental analysis of costs and consequences of alternatives performed? (ix) Was allowance made for uncertainty in the estimates of costs and consequences? $(x)$ Did the presentation and discussion of study results include all issues of concern to users?

All currencies were converted to 2015 Euros using the Cochrane web-based currency conversion tool: https://eppi.ioe.ac.uk/costconversion/default.aspx. Resource use was expressed in cost per person and classified as low (savings or $\leq$ USD 1,000/person (EUR 808)), moderate(USD 1,000-100,000/person (EUR $808-80,845)$ ) or high (USD $\geq 100,000 /$ person (EUR > 80,845)). 
TABLE 3B

Characteristics of included studies for resource use, costs, and cost-effectiveness of active tuberculosis screening

\begin{tabular}{|c|c|c|c|c|c|}
\hline Study & $\begin{array}{c}\text { Certainty of economic evidence } \\
\text { based on the Drummond } \\
\text { criteria }{ }^{\text {a }} \text { [27] }\end{array}$ & Methodological approach/population & Intervention(s) & $\begin{array}{l}\text { Cost-effectiveness } \\
\text { (ICER or INB) per } \\
\text { case prevented }\end{array}$ & $\begin{array}{c}\text { Resource } \\
\text { Requirements }\end{array}$ \\
\hline $\begin{array}{l}\text { Dasgupta et al. } \\
2000[34]\end{array}$ & $\begin{array}{l}\text { Certainty of evidence: low. } \\
\text { Limited allowance was made } \\
\text { for uncertainty in the estimates } \\
\text { of costs and consequences; } \\
\text { ranges were provided. } \\
\text { No PSA was performed } \\
\text { No one-way or two-way } \\
\text { sensitivity analyses using } \\
\text { higher or lower costs, other } \\
\text { discount rates or comparisons } \\
\text { were performed. } \\
\text { Scenario analyses undertaken. } \\
\text { The cost-effectiveness results } \\
\text { were sensitive to costs for } \\
\text { passive diagnosis of TB, INH } \\
\text { prescription rate, screening } \\
\text { referral criteria and future risk } \\
\text { of active TB. }\end{array}$ & $\begin{array}{l}\text { Methods: cost-effectiveness analysis } \\
\text { based on prospective non-randomised } \\
\text { cohorts; results reported in Canadian } \\
\text { dollars; prospective cohort study over } \\
1 \text { year of costs. }\end{array}$ & $\begin{array}{l}\text { Three strategies: } \\
\text { (i) CXR in migrants } \\
\text { applying for a } \\
\text { permanent residence } \\
\text { (ii) Surveillance CXR } \\
+/- \text { TST } \\
\text { (iii) Close contacts } \\
\text { CXR +/-TST }\end{array}$ & $\begin{array}{l}\text { Over } 1 \text { year, the } \\
\text { three programmes } \\
\text { detected } 27 \text { cases } \\
\text { of active TB and } \\
\text { prevented } 14 \text { future } \\
\text { cases. } \\
\text { Close-contact } \\
\text { screening resulted } \\
\text { in net savings } \\
\text { of CAD } 815 \text { (EUR } \\
758 \text { ) for each active } \\
\text { case detected and } \\
\text { treated and of } \\
\\
\text { CAD 2,186 (EUR } \\
2,033 \text { ) for each } \\
\text { future active } \\
\text { case prevented, } \\
\text { compared with } \\
\text { passive case } \\
\text { detection. }\end{array}$ & $\begin{array}{l}\text { Resource } \\
\text { requirements } \\
\text { were moderate } \\
\text { in applicants and } \\
\text { close contacts and } \\
\text { higher on those on } \\
\text { surveillance. } \\
\\
\text { Costs of TB detected } \\
\text { and treated: } \\
\text { Close contacts CXR } \\
\text { +/-TST: CAD 10,275 } \\
\text { (EUR 9,560); } \\
\text { Applicants CXR: CAD } \\
\text { 31,418 (EUR 29,232); } \\
\text { Those on } \\
\text { surveillance CXR } \\
\text { +/-TST: } 55,728 \text { (EUR } \\
\text { 51,850). }\end{array}$ \\
\hline $\begin{array}{l}\text { Oxlade et al. } 2007 \\
\text { [35] }\end{array}$ & $\begin{array}{l}\text { Allowance was made for } \\
\text { uncertainty in the estimates } \\
\text { of costs and consequences; } \\
\text { ranges were provided. } \\
\text { No PSA was performed } \\
\text { One-way or two-way sensitivity } \\
\text { analyses using higher or } \\
\text { lower costs, other discount } \\
\text { rates and test performance } \\
\text { characteristics were } \\
\text { undertaken. } \\
\text { The cost-effectiveness results } \\
\text { were sensitive to TST and } \\
\text { QFT sensitivity, costs of } \\
\text { TST and QFT, close contacts } \\
\text { investigation, the passive TB } \\
\text { case detection rate and risk of } \\
\text { re-activation. }\end{array}$ & $\begin{array}{c}\text { Methods: decision-analytic Markov } \\
\text { model; } 20 \text { year time horizon; } 3 \% \\
\text { discount rate; Canadian health system } \\
\text { perspective; Costs reported in } 2004 \\
\text { Canadian dollars. }\end{array}$ & $\begin{array}{l}\text { Five strategies: } \\
\text { (i) CXR } \\
\text { (ii) No screening } \\
\text { (iii) TST } \\
\text { (iv) QFT } \\
\text { (v) TST followed by } \\
\text { QFT if TST-positive }\end{array}$ & $\begin{array}{l}\text { ICER (CAD/case } \\
\text { prevented): } \\
\text { CXR vs no } \\
\text { screening: CAD } 875 \\
\text { (EUR 690); } \\
\text { TST vs CXR: CAD } \\
\text { 9,800 (EUR 7,738), } \\
\text { assuming that } \\
\text { prescription and } \\
\text { completion rates in } \\
\text { indicated patients } \\
\text { were } 100 \% \text { (relative } \\
\text { to the baseline } \\
\text { assumption of } 73 \% \\
\text { prescription and } \\
50 \% \text { completion). }\end{array}$ & $\begin{array}{c}\text { Resource } \\
\text { requirement were: } \\
\text { low to moderate } \\
\text { for CXR and } \\
\text { moderate for QFT } \\
\text { in immigrants from } \\
\text { medium and high } \\
\text { incidence countries; } \\
\text { high for CXR and } \\
\text { QFT in immigrants } \\
\text { from low-incidence } \\
\text { countries. } \\
\\
\text { Costs of CXR } \\
\text { SCreening ranged } \\
\text { from: } \\
\text { low TB incidence } \\
\text { Source ( } 2 / 100,000), \\
\text { CAD } 52,553 \text { (EUR } \\
41,499) ; \\
\text { high TB incidence } \\
\text { (120/100,000), } \\
\text { CAD } 328,190 \text { (EUR } \\
259,160) .\end{array}$ \\
\hline
\end{tabular}

CAD : Canadian dollar; CXR: chest radiography; EUR: Euro; HIV: human immunodeficiency virus; ICER: incremental cost-effectiveness ratio; INB: incremental net benefit; INH: isoniazid; PSA: probabilistic sensitivity analysis; QFT: quantiferon; TB: tuberculosis; TST: tuberculin skin test; USD: United States dollar.

a The Drummond Criteria [27]: (i) Was a well-defined question posed in answerable form? (ii) Was a comprehensive description of the competing alternatives given (i.e. can you tell who did what to whom, where and how often)? (iii) Was the effectiveness of the programme or services established? (iv) Were all the important and relevant costs and consequences for each alternative identified? (v) Were costs and consequences measured accurately in appropriate physical units (e.g. hours of nursing time, number of physician visits, lost working days, gained life years)? (vi) Were the cost and consequences valued credibly? (vii) Were costs and consequences adjusted for differential timing? (viii) Was an incremental analysis of costs and consequences of alternatives performed? (ix) Was allowance made for uncertainty in the estimates of costs and consequences? ( $x$ ) Did the presentation and discussion of study results include all issues of concern to users?

All currencies were converted to 2015 Euros using the Cochrane web-based currency conversion tool: https://eppi.ioe.ac.uk/costconversion/default.aspx. Resource use was expressed in cost per person and classified as low (savings or $\leq$ USD 1,000/person (EUR 808)), moderate(USD 1,000-100,000/person (EUR $808-80,845)$ ) or high (USD $\geq 100,000 /$ person (EUR > 80,845)). 
migrant type (asylum seekers: median: 350/100,000; interquartile range (IQR): $250-410$, and other migrants: median: 170; IQR: 100-630) and by setting where the screening was conducted (port of arrival: median: 360 ; IQR: 100-5,200, reception/holding centres: median: 290; IQR: $100-380$, community post arrival: median: 220; IQR: $100-380$, and occasional screening: median: 1,720; IQR: 730-2,740). The yield varied widely also between host countries, from as low as 110 per 100,000 in the Netherlands to as high as 2,340 per 100,000 in Italy, probably reflecting differences in migrant type, country of origin and circumstances of travel in the migrants screened [36]. Arshad et al. assessed the yield of active TB screening among migrants originating from intermediate or high TB incidence countries upon and after entry to low TB incidence countries and found a similar overall yield of active TB case detection of 349 per 100,00 population [28]. The yield also varied by migrant type (refugees: 1,192; 95\% confidence interval (Cl): $668-1,717$, regular migrants: $284 ; 95 \% \mathrm{Cl}$ : 204-364 and asylum seekers: 270; $95 \% \mathrm{Cl}$ : 198-342) and TB incidence in the country of origin (Europe: 236; 95\% Cl: $131-340$, Africa: $655 ; 95 \% \mathrm{Cl}: 319-990$ and Asia: 1,117; 95\% Cl: 625-1,608) [28]. Finally, Aldridge et al. assessed the yield of CXR screening for active TB among migrants in the pre-arrival TB screening programmes. No overall estimates were presented but the yield increased steadily with the TB incidence in migrant source countries. The yield was 19.6 per 100,000 in migrants originating from countries with a TB incidence lower than 50 per 100,000 and 336 per 100,000 in migrants originating from countries with a TB incidence greater than 350 per 100,000 [25]. The quality of the data in studies included in these three systematic reviews was very low to low (GRADE).

\section{Accuracy of chest radiography to detect active}

tuberculosis

We identified two systematic reviews that assessed the performance of CXR to detect active TB [30,31]. Van't Hoog et al. showed that CXR (presence of any abnormality) was highly sensitive ( $98 \%$ ) and moderately specific ( $75 \%)$ to detect active TB [30]. Screening for active TB with symptoms alone had lower sensitivity (78\%) and specificity (68\%) [30]. Pinto et al. also found that CXR to detect active TB was highly sensitive 95\% (range: $81-100 \%$ ) but less specific $42 \%$ (range: $22-72 \%$ ) [31]. Focussing on the presence of upper lobe infiltrates and cavities increased the predictive value for diagnosing active TB. The certainty of the evidence of these two studies was judged to be very low (Table 1).

Numbers needed to screen

Using inputs of the yield of CXR reported by Aldridge in the pre-arrival programmes we estimated the NNS to detect one case of active TB in migrants stratified by TB incidence in source countries (Table 2) [25]. We found that the NNS decreased dramatically with increasing TB incidence in source countries and ranged from 5,076 in countries with a TB incidence between
50 and 149 per 100,000 to 298 in countries with a TB incidence greater than 350 per 100,000.

Effectiveness of active tuberculosis treatment In an ECDC report on TB surveillance from 2007 to 2013, TB treatment outcomes were similar or better in those born outside the EU/EEA than in those born in the EU/EEA [6]. Treatment success was as high in the foreign-born (for all regions of origin) compared with those born in the EU/EEA ( $77.4 \%$ vs $74.6 \%$ ); however, their failure rates (0.2\% vs $2.4 \%$ ) and default rates (5.4\% to $6.6 \%$ ) were lower. This European surveillance data was judged to be high-quality evidence (Table 1 ).

Acceptability of screening

Mitchell et al. conducted a review to determine the acceptability of targeted TB screening and active case finding among vulnerable and at-risk groups and found that TB screening was well accepted by the majority of risk groups, including migrants ( $85 \%$; range: $55-96 \%$ ). Lower acceptability was found among persons living with HIV/AIDS and individuals in refugee camps and internally displaced persons [32]. Overall, the study found that simple TB screening (at point of care) was more acceptable than referral requiring multiple visits. The evidence in this study was judged to have considerable bias (Table 1 ).

\section{Cost-effectiveness of active tuberculosis screening programmes}

There was very little information on the cost-effectiveness of active TB screening in migrant populations as only three studies were identified. These studies demonstrated that the most cost-effective CXR screening strategies were among high-prevalence groups, close contacts of those with known TB, and migrants at entry if they originated from intermediate $(60 / 100,000)$ and high $(>120 / 100,000)$ TB incidence countries [33-35] (Table 3).

Two studies demonstrated that CXR screening of migrants was cost-effective compared with no screening: Oxlade et al. determined that the ICER of CXR relative to no screening was CAD 30,000 (Canadian dollars in 2004; EUR 23,690) per case averted in migrants from intermediate TB incidence source countries, and less than CAD 1,000 (EUR 789) per case averted in the high-incidence group [35]. Similarly, CXR compared with no screening in immigrants with a risk of reactivation of more than $5 \%$ was cost-effective. Dasgupta et al. reported that close-contact screening resulted in net savings of CAD 815 (EUR 758) for each active case detected and treated and of CAD 2,186 (EUR 2,033) for each future active case prevented, compared with passive case detection [34]. The certainty of the evidence in these studies ranged from low to moderate (Table 1).

\section{Discussion}

There were no single studies that directly addressed the overall effectiveness of active TB screening programmes on the health outcomes of migrant 
populations. We therefore evaluated the screening chain of evidence. The yield of detecting active TB through CXR screening of migrants was heterogeneous across studies and varied by migrant type and the setting in which the screening was done, but consistently increased with higher TB incidence in the country of origin $[25,28,29]$. The NNS to detect one case of active TB decreased and cost-effectiveness increased with increasing TB incidence in source countries [25,34,35]. CXR is a highly sensitive and moderately specific screening tool to detect active TB [30,31]. CXR screening is highly acceptable to most foreign-born populations [32].

The yield of CXR to detect active TB varied widely among migrant sub-groups in the three systematic reviews (120 to 2,340/100,000) however the overall yield $(350$ cases/100,000) in the post-arrival setting was consistent between studies [28,29]. There was also consistency in the increase in yield with increasing TB incidence in source countries in both pre- and postarrival setting $[25,28,29]$. The majority of studies in the post-arrival setting were carried out in various EU/EEA countries whereas pre-arrival screening was done in migrants arriving in the United Kingdom. The wide range in yield of post-arrival screening programmes reflects the heterogeneity of the programmes and the composition of migrants screened. Post-arrival programmes differed widely between countries with respect to timing of screening (port of arrival, in reception areas, in the community or ad hoc), countries of origin of migrants received, the type of migrants targeted (all migrants, asylum seekers only or undocumented migrants), and the threshold of TB incidence in the countries of origin at which screening was performed. Although $31 \mathrm{EU} /$ EEA countries have an active TB screening programme for migrants, the absolute and attributable impact on active TB rates in those countries is unknown $[37,38]$. Extrapolating from the impact of the well-established pre-migration TB programme in the US, there may be benefit of active TB screening in migrants on TB control in the host country. An evaluation of this programme demonstrated that detecting prevalent active TB before arrival in the US reduced TB notification rates among migrants in the first years after arrival [39].

Higher NNS and lower cost-effectiveness with higher $T B$ incidence in countries of origin suggests that active TB screening programmes will be most efficient when targeting migrant populations from high TB incidence countries. This is consistent with WHO recommendations to focus active screening on the highest risk groups [40]. The heterogeneity of the estimates from these studies, however, limits the ability to provide more precise guidance on which type of migrants to target, the best timing to screen or the optimal threshold of TB incidence in countries of origin. Although screening migrants from the highest TB incidence countries is most efficient, the impact on TB incidence in the host country might be limited since many cases occur in migrants from countries with lower TB incidence and in migrants who entered the country many years before TB diagnosis $[41,42]$.

Although the CXR is a good screening test for active TB and is highly sensitive (78\%), confirmatory sputum culture for TB is essential to improve specificity and is the gold standard for diagnosing active TB [30,31,43]. Screening for symptoms of active TB may be a reasonable first screening tool in certain situations such as in an emergency setting with no on-site CXR facilities. These situations include the reception centres in Italy and Greece and/or when the receipt of a large number of migrants overwhelm health systems (as occurred in Europe in 2015) [8]. Those with symptoms would need referral for CXR. The choice of the screening algorithm will need to be determined by the availability, feasibility and cost of the tests.

Active TB case finding in at-risk populations is an important TB control strategy as it allows for early detection and treatment, reduces individual morbidity and prevents TB spread to others. Active screening programmes are, however, limited by the fact that the yield is low (0.31-1.21\%) and that they do not capture or prevent the majority of incident TB cases occurring in the EU/EEA that are primarily due to reactivation of latent TB or new acquisition during travel [13]. Furthermore, the epidemiology of TB in the EU/EEA is heterogeneous. While migrants make up the majority of TB cases in low TB incidence EU/EEA countries, they make up a minority of cases in member states with higher TB incidence (Supplement 2). Screening for active TB in migrants will therefore need to be tailored to the local TB epidemiology in host countries, and the healthcare capacity in each setting $[2,3]$. Finally, many migrant sub-groups are vulnerable and face barriers in accessing heath care and treatment in the EU/EEA [44]. Addressing barriers in accessing care and treatment for all migrants, including the right to healthcare access for all and programmes tailored to address unique needs, will be essential to ensuring the most effective active TB screening and treatment programmes.

\section{Study limitations}

Our study was limited by the fact that we did not retrieve any studies that directly estimated the effectiveness of active TB screening and by the very limited data on the cost-effectiveness of active TB screening. The search was limited by the fact that it was conducted up until May 2016 and that we only included studies published in English or French. A recent narrative review of the effectiveness and cost-effectiveness, however, reports similar literature and findings as our study [45]. Our findings are further limited by the quality of the original studies that were included in the systematic reviews. Study quality was low or very low, as almost all included studies were observational studies.

\section{Evidence gaps and future directions}

Robust studies on the yield of active TB screening among migrants by age group, migration type, timing of 
screening, threshold of TB incidence in source countries and the associated cost-effectiveness will be required to design the most effective active TB screening programmes. Additional studies are needed that determine the absolute and attributable impact of active TB programmes on TB control in low-incidence countries in the EU/EEA and the optimal threshold of incidence in source countries at which to screen. Finally, evidence on the comparative effectiveness and cost-effectiveness of different TB control strategies (active vs latent TB screening) for migrants will be required to prioritise TB control efforts for this population.

\section{Conclusions}

Active TB screening programmes that target migrants from high TB incidence countries will provide the highest yield and will be the most cost-effective. The heterogeneity of the estimates from the studies identified and the small number of studies addressing both the effectiveness and cost-effective of active TB screening in migrants limits the ability to provide precise guidance on which type of migrants to target, the best timing to screen or the optimal threshold of TB incidence in countries of origin. This highlights the need for further data to inform active TB screening programmes for migrants in the EU/EEA.

\section{Acknowledgements}

Funding: This work is supported by the European Centre for Disease Prevention and Control (ECDC); FWC No ECDC/2015/016; Specific Contract No 1 ECD.5748. Dr Manish Pareek is supported by the National Institute for Health Research (NIHR Post-Doctoral Fellowship, Dr Manish Pareek, PDF-2015-08-102). The views expressed in this publication are those of the author(s) and not necessarily those of the NHS, the National Institute for Health Research or the Department of Health. Prof Rachael L Morton is supported by an NHMRC Public Health Fellowship \#1054216.

\section{Conflict of interest}

KP led and CG was an author on the Canadian Migrant Guidelines including TB. AM co-led the work on the WHO LTBI screening guidelines. MP holds a Gilead Sciences grant for a project outside of the submitted work.

\section{Authors' contributions}

CG, DZ, MP, AM, RLM, TN and KP contributed to the design and research questions. KP, RC were part of the core methods team members for the ECDC Guidelines project developing the methods. DZ, MP, MvW and AM provided substantial content on the research question and design. CG, IM, BA and $\mathrm{MW}$ wrote the manuscript. CNAC, MW, BS, TM, CH and $A M$ reviewed and selected the literature, and extracted and synthesised the data. RLM, AT, and NR conducted the review and synthesised the data for cost-effectiveness analysis. All authors read and approved the manuscript.

\section{References}

1. European Centre for Disease Prevention and Control (ECDC). Guidance on tuberculosis control in vulnerable and hard-to-reach populations. Stockholm: ECDC; 2016. Available from: https://ecdc.europa.eu/sites/portal/files/media/ en/publications/Publications/TB-guidance-interventionsvulnerable-groups.pdf

2. European Centre for Disease Prevention and Control (ECDC). Progressing towards TB elimination. Stockholm: ECDC; 2010. Available from: https://ecdc.europa.eu/sites/portal/files/ media/en/publications/Publications/101111_SPR_Progressing_ towards_TB_elimination.pdf

3. Lönnroth K, Migliori GB, Abubakar I, D’Ambrosio L, de Vries G, Diel R, et al. Towards tuberculosis elimination: an action framework for low-incidence countries. Eur Respir J. 2015;45(4):928-52. PMID: 25792630

4. World Health Organisation (WHO). Towards TB elimination. An action framework for low-incidence countries. Geneva: WHO; 2014. Available from: http://apps.who.int/iris/ bitstream/10665/132231/1/9789241507707_eng.pdf?ua=1

5. European Centre for Disease Prevention and Control (ECDC)/ World Health Organization Regional Office for Europe. Tuberculosis surveillance and monitoring in Europe 2017. Stockholm: ECDC; 2017. Available from: https://ecdc. europa.eu/sites/portal/files/documents/ecdc-tuberculosissurveillance-monitoring-Europe-2017-WEB.pdf

6. Ködmön C, Zucs P, van der Werf MJ. Migration-related tuberculosis: epidemiology and characteristics of tuberculosis cases originating outside the European Union and European Economic Area, 2007 to 2013. Euro Surveill. 2016;21(12):30164. https://doi.org/10.2807/1560-7917.ES.2016.21.12.30164 PMID: 27039665

7. Eurostat. Migration and migrant population statistics. Luxembourg: European Commission. [Accessed: 30 Jan 2017]. Available from: http://ec.europa. eu/eurostat/statistics-explained/index.php/ Migration_and_migrant_population_statistics

8. International Organization for Migration (IOM). Migration flows - Europe. Geneva: IOM. [Accessed: 15 May 2017]. Available from: http://migration.iom.int/europe/

9. Eurostat. European social statistics. Luxembourg; 2013.

10. World Health Organisation (WHO) Strategic and Technical Advisory Group for TB. (STAG-TB). Use of high burden country lists for TB by WHO in the post-2015 era. Geneva: WHO; 2015. Available from: http://www.who.int/tb/publications/global_ report/high_tb_burdencountrylists2016-2020.pdf

11. Hollo V, Kotila SM, Ködmön C, Zucs P, van der Werf MJ. The effect of migration within the European Union/European Economic Area on the distribution of tuberculosis, 2007 to 2013. Euro Surveill. 2016;21(12):30171. https://doi. org/10.2807/1560-7917.ES.2016.21.12.30171 PMID: 27035746

12. Hollo V, Beauté J, Ködmön C, van der Werf MJ. Tuberculosis notification rate decreases faster in residents of native origin than in residents of foreign origin in the EU/EEA, 2010 to 2015. Euro Surveill. 2017;22(12):30486. https://doi. org/10.2807/1560-7917.ES.2017.22.12.30486 PMID: 28367798

13. Pareek M, Greenaway C, Noori T, Munoz J, Zenner D. The impact of migration on tuberculosis epidemiology and control in highincome countries: a review. BMC Med. 2016;14(1):48. https:// doi.org/10.1186/s12916-016-0595-5 PMID: 27004556

14. Pareek M, Baussano I, Abubakar I, Dye C, Lalvani A. Evaluation of immigrant tuberculosis screening in industrialized countries. Emerg Infect Dis. 2012;18(9):1422-9. https://doi. org/10.3201/eid1809.120128 PMID: 22931959

15. Kunst H, Burman M, Arnesen TM, Fiebig L, Hergens MP, Kalkouni 0 , et al. Tuberculosis and latent tuberculous infection screening of migrants in Europe: comparative analysis of policies, surveillance systems and results. Int J Tuberc Lung Dis. 2017;21(8):840-51. https://doi.org/10.5588/ijtld.17.0036 PMID: 28786791

16. Schünemann HJ, Wiercioch W, Brozek J, Etxeandia-Ikobaltzeta I, Mustafa RA, Manja V, et al. GRADE Evidence to Decision (EtD) frameworks for adoption, adaptation, and de novo development of trustworthy recommendations: GRADEADOLOPMENT. J Clin Epidemiol. 2017;81:101-10. https://doi. org/10.1016/j.jclinepi.2016.09.009 PMID: 27713072

17. Pottie K, Mayhew AD, Morton RL, Greenaway C, Akl EA, Rahman P, et al. Prevention and assessment of infectious diseases among children and adult migrants arriving to the European Union/European Economic Association: a protocol for a suite of systematic reviews for public health and health systems. BMJ Open. 2017;7(9):e014608. https://doi. org/10.1136/bmjopen-2016-014608 PMID: 28893741

18. Moher D, Liberati A, Tetzlaff J, Altman DGPRISMA Group. Preferred reporting items for systematic reviews and meta-analyses: the PRISMA statement. Ann Intern Med. 2009;151(4):264-9, W64. https://doi.org/10.7326/0003-4819151-4-200908180-00135 PMID: 19622511 
19. Woolf S, Schünemann HJ, Eccles MP, Grimshaw JM, Shekelle P. Developing clinical practice guidelines: types of evidence and outcomes; values and economics, synthesis, grading, and presentation and deriving recommendations. Implement Sci. 2012;7(1):61. https://doi.org/10.1186/1748-5908-7-61 PMID: 22762158

20. Kahwati LC, Feltner C, Halpern M, Woodell CL, Boland E, Amick HR, et al. Primary care screening and treatment for latent tuberculosis infection in adults: evidence report and systematic review for the US Preventive Services Task Force. JAMA. 2016;316(9):970-83. https://doi.org/10.1001/ jama.2016.10357 PMID: 27599332

21. Greenaway C, Sandoe A, Vissandjee B, Kitai I, Gruner D, Wobeser W, et al. Tuberculosis: evidence review for newly arriving immigrants and refugees. CMAJ. 2011;183(12):E939-51. https://doi.org/10.1503/cmaj.090302 PMID: 20634392

22. Shea BJ, Hamel C, Wells GA, Bouter LM, Kristjansson E, Grimshaw J, et al. AMSTAR is a reliable and valid measurement tool to assess the methodological quality of systematic reviews. J Clin Epidemiol. 2009;62(10):1013-20. https://doi. org/10.1016/j.jclinepi.2008.10.009 PMID: 19230606

23. Wells G, Shea B, O'Connell B, Peterson J, Welch V, Losos M, et al. The Newcastle-Ottawa Scale (NOS) for assessing the quality of nonrandomised studies in meta-analyses. Ottawa: Ottawa Hospital Research Institute. [Accessed: Oct 2016]. Available from: http://www.ohri.ca/programs/clinical_epidemiology/ oxford.asp

24. Guyatt G, Oxman AD, Akl EA, Kunz R, Vist G, Brozek J, et al. GRADE guidelines: 1 . Introduction-GRADE evidence profiles and summary of findings tables. J Clin Epidemiol. 2011;64(4):38394. https://doi.org/10.1016/j.jclinepi.2010.04.026 PMID: 21195583

25. Aldridge RW, Yates TA, Zenner D, White PJ, Abubakar I, Hayward AC. Pre-entry screening programmes for tuberculosis in migrants to low-incidence countries: a systematic review and meta-analysis. Lancet Infect Dis. 2014;14(12):12409. https://doi.org/10.1016/S1473-3099(14)70966-1 PMID: 25455991

26. Alonso-Coello P, Oxman AD, Moberg J, Brignardello-Petersen R, Akl EA, Davoli M, et al. GRADE Evidence to Decision (EtD) frameworks: a systematic and transparent approach to making well informed healthcare choices. 2: Clinical practice guidelines. BMJ. 2016;353:i2089. https://doi.org/10.1136/bmj. i2089 PMID: 27365494

27. Drummond MFSM, Torrance GW, O’Brien BJ, Stoddart GL. Methods for the economic evaluation of health care programmes. 2nd edition. New York: Oxford University Press; 1997. 396 p.

28. Arshad S, Bavan L, Gajari K, Paget SN, Baussano I. Active screening at entry for tuberculosis among new immigrants: a systematic review and metaanalysis. Eur Respir J. 2010;35(6):1336-45. https://doi. org/10.1183/09031936.00054709 PMID: 19840970

29. Klinkenberg E, Manissero D, Semenza JC, Verver S. Migrant tuberculosis screening in the EU/EEA: yield, coverage and limitations. Eur Respir J. 2009;34(5):1180-9. https://doi. org/10.1183/09031936.00038009 PMID: 19880618

30. Van't Hoog A, Langendam M, Mitchell E, Cobelens F, Sinclair $D$, Leeflang $M$, et al. A systematic review of the sensitivity and specificity of symptom-and chest-radiography screening for active pulmonary tuberculosis in HIV-negative persons and persons with unknown HIV status. Geneva: World Health Organization; 2013. Available from: http://www.who.int/tb/ Review2Accuracyofscreeningtests.pdf?ua=1

31. Pinto LM, Pai M, Dheda K, Schwartzman K, Menzies D, Steingart KR. Scoring systems using chest radiographic features for the diagnosis of pulmonary tuberculosis in adults: a systematic review. Eur Respir J. 2013;42(2):480-94. https:// doi.org/10.1183/09031936.00107412 PMID: 23222871

32. Mitchell EMH, Shapiro A, Golub J, Kranzer K, Portocarrero AV, Najlis CA, et al. Acceptability of TB screening among at-risk and vulnerable groups: a systematic qualitative/quantitative literature metasynthesis. Geneva: World Health Organization; 2013. Available from: http://www.who.int/entity/tb/ Review4aAcceptabilityofscreeningRISK_GROUPS.pdf?ua=1

33. Schwartzman K, Menzies D. Tuberculosis screening of immigrants to low-prevalence countries. A cost-effectiveness analysis. Am J Respir Crit Care Med. 2000;161(3 Pt 1):780-9. https://doi.org/10.1164/ajrccm.161.3.9902005 PMID: 10712322

34. Dasgupta K, Schwartzman K, Marchand R, Tennenbaum TN, Brassard P, Menzies D. Comparison of cost-effectiveness of tuberculosis screening of close contacts and foreign-born populations. Am J Respir Crit Care Med. 2000;162(6):2079-86. https://doi.org/10.1164/ajrccm.162.6.2001111 PMID: 11112118

35. Oxlade O, Schwartzman K, Menzies D. Interferon-gamma release assays and TB screening in high-income countries: a cost-effectiveness analysis. Int J Tuberc Lung Dis. 2007;11(1):16-26. PMID: 17217125

36. van der Werf MJ, Zellweger JP. Impact of migration on tuberculosis epidemiology and control in the EU/EEA. Euro Surveill. 2016;21(12):30174. https://doi.org/10.2807/15607917.ES.2016.21.12.30174 PMID: 27035852

37. D’Ambrosio L, Centis R, Dara M, Solovic I, Sulis G, Zumla A, et al. European policies in the management of tuberculosis among migrants. Int J Infect Dis. 2017;56:85-9. https://doi. org/10.1016/j.ijid.2016.11.002 PMID: 27836793

38. Dara M, Solovic I, Sotgiu G, D’Ambrosio L, Centis R, Tran R, et al. Tuberculosis care among refugees arriving in Europe: a ERS/ WHO Europe Region survey of current practices. Eur Respir J. 2016;48(3):808-17. https://doi.org/10.1183/13993003.008402016 PMID: 27492827

39. Liu Y, Posey DL, Cetron MS, Painter JA. Effect of a culturebased screening algorithm on tuberculosis incidence in immigrants and refugees bound for the United States: a population-based cross-sectional study. Ann Intern Med. 2015;162(6):420-8. https://doi.org/10.7326/M14-2082 PMID: 25775314

40. World Health Organisation (WHO). Systematic screening for active tuberculosis: principles ad recommendations. Geneva: WHO; 2013. Available from: http://www.who.int/tb/ tbscreening/en/

41. Slump E, Erkens C, van Hunen R, Schimmel H, van Soolingen D, de Vries G. Tuberculose in Nederland 2015: Surveillancerapport inclusief rapportage monitoring van interventies.

[Tuberculosis in the Netherlands 2015: Surveillance report including reporting monitoring of interventions]. Bilthoven: National Institute for Public Health and the Environment (RIVM) 2016. Dutch. Available from: https://www.rivm.nl/ dsresource?objectid=378ba7b3-c3ba-4707-8f9o-f175agd18d98 \&type $=$ pdf\&disposition $=$ inline

42. Public Health England (PHE). Tuberculosis in England 2016 report (presenting data to end of 2015). London: PHE; 2016. Available from: https://www.tbalert.org/wp-content/ uploads/2016/09/PHE TB Annual_Report_2016.pdf

43. Forbes B, Banaiee N, Beavis K, Brown-Elliott B, Della Latta $P$, Elliott $B$, et al. Laboratory detection and identification of Mycobacteria; approved guideline. M48-A. Wayne: Clinical Laboratory Standards Institute (CLSI); 2008. ISSN 0273-3099. Available from: https://clsi.org/media/1447/m48a_sample.pdf

44. Rechel B, Mladovsky P, Ingleby D, Mackenbach JP, McKee M. Migration and health in an increasingly diverse Europe. Lancet. 2013;381(9873):1235-45. https://doi.org/10.1016/S01406736(12)62086-8 PMID: 23541058

45. Zenner D, Hafezi H, Potter J, Capone S, Matteelli A. Effectiveness and cost-effectiveness of screening migrants for active tuberculosis and latent tuberculous infection. Int Tuberc Lung Dis. 2017;21(9):965-76. https://doi.org/10.5588/ ijtld.16.0935 PMID: 28826445

\section{License and copyright}

This is an open-access article distributed under the terms of the Creative Commons Attribution (CC BY 4.0) Licence. You may share and adapt the material, but must give appropriate credit to the source, provide a link to the licence, and indicate if changes were made.

This article is copyright of the authors, 2018. 